\title{
Characterization of enzymatically extracted sunflower seed oil as well as the protein residues
}

\author{
By M.Z. Sitohy (1), E.H. Badr (1), M. Perifanova-Nemska (2) and T.S. Khadjiski (2) \\ (1) Biochemistry Department and Food Science Department, Faculty of Agriculture, Zagazig University, EGYPT. \\ (2) Department of Essential Oils and Fatty Acids, Plovdiv, BULGARIA.
}

\section{RESUMEN}

Caracterización de aceite de semilla de girasol extraído enzimáticamente así como de los residuos proteínicos.

Aceite de semilla de girasol fue extraído enzimáticamente con seis enzimas diferentes: celulasa, hemicelulasa, proteinasa animal, proteinasa ácida, pectinasa y pectinex bajo las condiciones siguientes: concentración de sustrato en tampón fosfato $(0,5 \mathrm{M}, \mathrm{pH} 5) 30 \%$, concentración enzimática $2 \%(E / S)$, temperatura $50^{\circ} \mathrm{C}$ y tiempo 3 horas. Los aceites obtenidos fueron analizados por sus propiedades fisicoquímicas y perfiles de ácidos grasos. Los residuos proteínicos fueron analizados por sus composiciones en aminoácidos.

Los resultados mostraron que la extracción enzimática con celulasa o hemicelulasa podían proporcionar buena calidad en los aceites, ya que sus niveles de ácidos linoleico y oleico registraron valores similares a los del aceite control extraído con disolventes orgánicos. También el valor de índice de iodo fue similar al del control. Por otro lado, el uso de proteasas en la extracción enzimática de aceite de semilla de girasol causó algunas reducciones en los niveles de ácidos grasos insaturados, así como en el índice de iodo. Las pectinasas mostraron una tendencia similar a la de las proteinasas con la menor obtención de ácido linoleico entre los diferentes aceites en estudio.

Del mismo modo, el uso de celulasas no cambió la composición de aminoácidos del residuo proteínico comparado con el control, por el contrario la extracción con proteinasas causó una disminución de algunos aminoácidos, especialmente lisina, leucina, isoleucina, alanina, arginina y aspártico. A este respecto, el uso de pectinasa se portó de manera análoga al de celulasas.

PALABRAS-CLAVE: Aceite de girasol - Extracción enzimática - Propiedades físico-químicas - Residuo proteínico.

\section{SUMMARY}

Characterization of enzymatically extracted sunflower seed oil as well as the protein residues.

Sunflower seed oil was enzymatically extracted with six different enzymes: cellulase, hemicellulase, animal proteinase, acid proteinase, pectinase and pectinex under the following conditions: substrate concentration in phosphate buffer $(0.5 \mathrm{M}, \mathrm{pH} 5) 30 \%$, enzyme concentration $2 \%(\mathrm{E} / \mathrm{S})$, temperature $50^{\circ} \mathrm{C}$ and time 3 hours. The obtained oils were analyzed for physicochemical properties and fatty acid profiles. The protein residues were analyzed for amino acid compositions.

The results showed that the enzymatic extraction with cellulase or hemicellulase could maintain good oil quality of the extracted oils as their levels of linoleic and oleic acids recorded similar values to those of the control oil extracted with organic solvents. Also the level of iodine value was in the same level of control. On the other hand, the use of proteases in the enzy- matic extraction of sunflower seed oil caused some reductions in the levels of the unsaturated fatty acids as well as the iodine value. The pectinases showed a similar trend to that of the proteinase with the least recovery of linoleic acid among the different oils under study.

Similarly, the use of cellulases did not change the amino acid composition of the protein residue as compared to the control, in the contrary to the extraction with the proteinases which caused reduction of some amino acids from the protein residues especially lysine, leucine, iso-leucine, alanine, arginine and aspartic. In that respect the use of pectinases behaved similar to cellulases.

KEY-WORDS: Enzymatic extraction - Physico-chemical properties Protein residue - Sunflower oil.

\section{INTRODUCTION}

Currently, the use of enzymatic extraction of vegetable oils is being studied as a new approach to avoid possible hygienic hazards which are associated with the use of organic solvents for oil extraction (Lorenz 1980; Mc-Glone et al 1986; Olsen 1988; Badr and Sitohy 1992).

Enzymes of different specificity have been found efficient tools in extracting sunflower seed oil in aqueous conditions. The enzyme action was attributed to the degrading activity of the different enzyme which is supposed to be capable of breaking the linkages between oil molecules and the other biomacromolecules in the vegetable cells either proteins, cellulose or pectin (Badr and Sitohy 1992). However, it is still pertinent in that context to characterize the oils obtained by such enzymatic extraction and compare them to those conventionally extracted with organic solvents. This may allow more comprehensive evaluation of the use of different enzymes in oil extraction. The characterization of the protein residues will also give some idea about the economics of this process.

\section{MATERIALS AND METHODS}

Sunflower seeds were obtained from local market in Zagazig. Animal proteinase and acid proteinase were obtained from the Institute of Microbiology, Sofia, Bulgaria. Cellulase 9108, hemicellulase AS and pectinase were 
obtained from Rapidase Seclin, France. Pectinex ultra SP was purchased from Novo Industri A/S Bagsvaerd, Danemark.

\subsection{Enzymatic extraction of oil}

Sunflower seeds were dehulled and chopped. An amount of $50 \mathrm{~g}$ of the chopped material was combined with phosphate buffer $(0.5 \mathrm{M}, \mathrm{pH} 5)$ to bring up the final substrate concentration into $30 \%$. Each of the six mentioned enzymes was applied separately at a rate of $2 \%$ (Enzyme/Substrate). The contents were continuously stirred with heating at $50^{\circ} \mathrm{C}$ for 3 hours. At the end of the extraction time, the enzyme was inactivated by the addition of $10 \mathrm{ml}$ benzene. The resulting emulsions were centrifuged at $3000 \mathrm{rpm}$ for 15 minutes. The oil-solvent layer was decanted and filtered through anhydrous sodium sulfate. Then, the benzene was evaporated in Soxhlet apparatus and the remained oil was taken for analysis of physicochemical properties and fatty acid profiles with gas chromatography according to the methods outlined in the AOAC 1980. The residue left after oil extraction was analyzed for amino acid composition with Amino Acid Analyzer (LKB 4151 Alpha plus) after being hydrolysed with $6 \mathrm{~N} \mathrm{HCl}$ at 110 for 22 hours. Tryptophane was determined in the alkaline hydrolysate of protein according to Blauth et al 1963.

\subsection{Oil extraction with organic solvent}

An amount of $50 \mathrm{~g}$ of the chopped seed material was extracted with n-hexane in Soxhlet apparatus for 6 hours. The oil obtained was considered as the control and analyzed similarly as for the other studied oils.

\section{RESULTS AND DISCUSSIONS}

The data presented in Table I generally show that there were no big changes in the general fatty acid composition of the sunflower seed oil extracted with different hydrolytic enzymes as compared to each other or to the control ( $n$ hexane extract). However, the oils extracted with proteases showed slightly reduced contents of linoleic. In addition, the oils extracted with pectinase or pectinex gave the least recoveries of that fatty acid. Hence, it might be concluded that both proteases and pectinases were not fully efficient in degrading the linkages between linoleic - containing lipids and cell constituents especially cellulose. This is particularly true since the extraction with cellulases was as efficient as the organic solvent in recovering high level of linoleic acid (Table I).

It might also be observed that the oil extracted with pectinases contained relatively high contents of oleic acid. However, this increase might be a direct arithmetic result of the evident reduction of linoleic in that case.

On the whole, it is noticed that the total content of the unsaturated fatty acids was slightly reduced in the oils extracted with either proteases or pectinases as compared to either cellulases or organic solvent extracted oils. So, it can be imagined that triglycerides containing unsaturated fatty acids might tend to exist associated to the cellulose component of the cells. Yet, the level of the unsaturated fatty acids is still within the high range of the known vegetable oils.

The overall physicochemical properties of different sunflower seed oils extracted with either enzymes of organic solvents are shown in Table II. It can be noticed that neither specific gravity nor refractive index was affected by the enzymatic processing as compared to the control. On the other hand, saponification number was noticeably augmented in the sunflower seed oils extracted with either proteases or pectinases. These increases might be due to the relative increases in the short chain fatty acids in the oils extracted with these two enzymes (Table I). Hence, it might be imagined that the triglycerides with shorter chain fatty acids might be in better access to the enzymatic actions than those with the longer ones which are supposed to be more hydrophobic.

Table I

Fatty acid profiles of sunflower seed oils as extracted with either hydrolytic enzymes or organic solvent (\% of total fatty acids)

\begin{tabular}{|c|c|c|c|c|c|c|c|}
\hline \multirow[b]{2}{*}{ Fatty acid } & \multicolumn{6}{|c|}{ Extracting reagent } & \multirow[b]{2}{*}{ Pectinex } \\
\hline & n-Hexane & Cellulase & $\begin{array}{c}\text { Hemi } \\
\text { cellulase }\end{array}$ & $\begin{array}{c}\text { Animal } \\
\text { proteinase }\end{array}$ & $\begin{array}{c}\text { Acid } \\
\text { proteinase }\end{array}$ & Pectinase & \\
\hline Caproic & $t^{\star}$ & 0.00 & $t$ & 0.00 & 0.00 & $t$ & $t$ \\
\hline Caprylic & 0.71 & 0.69 & 0.76 & 0.86 & 0.91 & 0.84 & 0.82 \\
\hline Capric & 0.30 & 0.42 & 0.38 & 0.42 & 0.55 & 0.41 & 0.45 \\
\hline Lauric & 2.81 & 2.91 & 2.88 & 1.54 & 1.66 & 2.81 & 2.78 \\
\hline Myristic & 0.09 & 0.12 & 0.16 & 0.81 & 0.76 & $t$ & $t$ \\
\hline Palmitic & 3.08 & 3.10 & 3.09 & 4.11 & 3.72 & 3.72 & 3.85 \\
\hline Stearic & 10.23 & 11.08 & 11.01 & 11.32 & 11.57 & 11.71 & 11.82 \\
\hline Oleic & 44.12 & 43.06 & 42.91 & 44.04 & 44.70 & 49.12 & 50.11 \\
\hline Linoleic & 37.11 & 38.01 & 37.91 & 35.07 & 35.22 & 29.97 & 29.18 \\
\hline Sat. F.A. & 18.77 & 18.93 & 19.18 & 20.89 & 20.08 & 20.91 & 20.71 \\
\hline Unsat. F.A. & 81.23 & 81.07 & 80.82 & 79.11 & 79.92 & 79.09 & 79.29 \\
\hline
\end{tabular}

* Traces. 
Table II

Physicochemical properties of sunflower seed oil extracted with either enzymes or organic solvent

\begin{tabular}{lcccc}
\hline $\begin{array}{l}\text { Extracting } \\
\text { reagent }\end{array}$ & $\begin{array}{c}\text { Specific } \\
\text { gravity at } 20^{\circ} \mathrm{C}\end{array}$ & $\begin{array}{c}\text { Refractive } \\
\text { index at } 20^{\circ} \mathrm{C}\end{array}$ & $\begin{array}{c}\text { Saponification } \\
\text { number }\end{array}$ & $\begin{array}{c}\text { lodine } \\
\text { value }\end{array}$ \\
\hline n-Hexane & 0.970 & 1.472 & 187.1 & 125.6 \\
Cellulase & 0.972 & 1.474 & 186.2 & 126.4 \\
$\begin{array}{l}\text { Hemicellulase } \\
\text { Animal }\end{array}$ & 0.974 & 1.475 & 187.9 & 126.1 \\
proteinase & 0.971 & 1.472 & 189.2 & 124.8 \\
Acid proteinase & 0.974 & 1.475 & 190.3 & 124.9 \\
Pectinase & 0.973 & 1.473 & 192.1 & 122.1 \\
Pectinex & 0.972 & 1.474 & 192.4 & 123.0 \\
\hline
\end{tabular}

Parallely, some reductions in iodine value can be noticed in the oils extracted with either proteases or pectinases. Likewise, these reductions are related to the decreased contents of the unsaturated fatty acids in the oils extracted with either proteases or pectinases.

On the other hand, the extraction with cellulases produced oils very similar to control in their physicochemical properties. Hence, for better oil quality the use of cellulases might be preferred to other enzymes.

The data in Table III represent the amino acid composition of the protein residues remaining after oil extraction. The general view shows that the residues of the enzymatic extraction with proteases are the only ones which are remarkably different from control. They showed reduced values of the amino acids: lysine, arginine, leucine, isoleucine, alanine and aspartic as compared to control or other enzymatic processings. It is understood in that concern that with the use of proteases the protein components are expected to be subjected to some degree of degradation. The extent of that degradation is dependent on the enzyme

specificity and activity as well as the nature of the protein substrate. Generally, it can be noticed that there was no distinction between the two studied proteases in their degrading action. So, it may be the nature of the protein structure which rendered the aforementioned six amino acids to be more liable to the enzyme action and hence being leached from the protein residues. As a result of these reductions in the six mentioned amino acids, other amino acids were arithmetically enhanced in these protein residues:

With the other two types of enzyme extraction the amino acid composition of the protein residues did not deviate from that of the control. So, it may be stated that although proteases were more efficient in extracting sunflower seed oil on quantitative basis (Badr and Sitohy 1992) yet they may pose some deterioration either in the quality of the extracted oil or the protein residue. So, it may be recommended to use either cellulases or find out some suitable combination between proteases and cellulases so as to achieve both high quality and quantity.

\section{REFERENCES}

1. AOAC (1980).-«Official Methods of Analysis of the Association of Official Analytical Chemists". -13 th ed.-Washington, DC.

2. Badr, F.H. and Sitohy, M.Z. (1992).- «Optimizing conditions for enzymatic extraction of sunflower seed oil».-Grasas y Aceites 43, 281-283.

3. Blauth, O.J., Chareinski, M. and Berlie, H. (1963).- «A new rapid method for determination of tryptophan".-Anal. Biochem. 6, 69.

4. Lorenz, K. (1980).-«Enzyme activities in non-oilseed sunflowers and sunflower products».-Food Chem. 5, 155-161.

5. Mc-Glone, O.C., Canales, A.L.M. and Carter, J.V. (1986).-«Coconut oil extraction by a new enzymatic process».-J. Food Sci. 51, 695-697.

6. Olsen, H.S. (1988).-«Aqueous enzymatic extraction of oil from seeds".-Paper presented at the Asian Food Conference 88, 24-26 Oct. 1988 Bangkok, Thailand.

(Recibido: Julio 1993)

Table III

Amino acid composition sunflower seed protein residues after oil extraction (g/100 g protein)

\begin{tabular}{|c|c|c|c|c|c|c|c|}
\hline \multirow[b]{2}{*}{ Amino acid } & \multicolumn{7}{|c|}{ Extracting reagent } \\
\hline & n-Hexane & Cellulase & $\begin{array}{c}\text { Hemi } \\
\text { cellulase }\end{array}$ & $\begin{array}{c}\text { Animal } \\
\text { proteinase }\end{array}$ & $\begin{array}{c}\text { Acid } \\
\text { proteinase }\end{array}$ & Pectinase & Pectinex \\
\hline Valine & 5.66 & 5.71 & 5.70 & 5.80 & 5.96 & 5.72 & 5.77 \\
\hline Isoleucine & 4.65 & 4.62 & 4.61 & 3.98 & 3.95 & 4.71 & 4.69 \\
\hline Leucine & 6.81 & 6.86 & 6.85 & 4.91 & 5.12 & 6.85 & 6.84 \\
\hline Lysine & 3.98 & 3.91 & 3.90 & 2.70 & 2.97 & 3.82 & 3.81 \\
\hline Methionine & 2.46 & 2.42 & 2.44 & 3.17 & 3.21 & 2.38 & 2.36 \\
\hline Cysteine & 1.70 & 1.71 & 1.69 & 2.10 & 2.51 & 1.61 & 1.62 \\
\hline Threonine & 3.49 & 3.52 & 3.51 & 4.16 & 3.92 & 3.12 & 3.51 \\
\hline Tryptophane & 1.49 & 1.49 & 1.46 & 1.40 & 1.42 & 1.38 & 1.41 \\
\hline Tyrosine & 2.90 & 2.81 & 2.83 & 3.12 & 3.16 & 2.81 & 2.91 \\
\hline Phenyl alanine & 5.20 & 5.24 & 5.31 & 4.99 & 4.85 & 5.32 & 5.37 \\
\hline Alanine & 4.30 & 4.31 & 4.29 & 2.80 & 2.71 & 4.28 & 4.21 \\
\hline Arginine & 9.36 & 9.31 & 9.32 & 7.81 & 7.91 & 9.06 & 9.11 \\
\hline Aspartic & 9.30 & 9.26 & 9.24 & 8.92 & 8.97 & 9.36 & 9.41 \\
\hline Glycine & 5.36 & 5.38 & 5.41 & 5.91 & 5.82 & 5.16 & 5.19 \\
\hline Glutamic & 21.26 & 21.34 & 21.32 & 20.71 & 21.09 & 22.01 & 21.81 \\
\hline Proline & 5.19 & 5.22 & 5.21 & 5.42 & 5.26 & 4.81 & 4.91 \\
\hline Serine & 4.15 & 4.17 & 4.16 & 6.13 & 6.28 & 4.06 & 4.12 \\
\hline Histidine & 2.66 & 2.68 & 2.67 & 3.81 & 3.91 & 2.71 & 2.61 \\
\hline
\end{tabular}

